\title{
INFLUENCE OF CHROMIUM CONTENT ON THE MECHANICAL PROPERTIES AND HAZ SIMULATIONS OF LOW-CARBON BAINITIC STEELS
}

\author{
Tun Tun NYO, Antti KAIJALAINEN, Jaakko HANNULA, Mahesh SOMANI, Jukka KÖMI \\ Materials and Mechanical Engineering, CASR, University of Oulu, Finland, EU, tun.nyo@oulu.fi
}

https://doi.org/10.37904/metal.2019.712

\begin{abstract}
During thermomechanically controlled processing (TMCP) of carbon steels, controlled rolling in norecrystallization regime followed by directing quenching results in excellent mechanical properties, besides enabling cost-saving in respect of energy costs normally incurred during reheating and quenching procedure. The effects of three different combinations of $\mathrm{Cr}$ with $0.06 \mathrm{wt} . \%$ of $\mathrm{Nb}$ on the microstructures and mechanical properties of thermomechanically rolled and direct-quenched low-carbon $(0.035 \mathrm{wt} . \%)$ microalloyed steel plates have been investigated to obtain balanced mechanical properties. Laboratory-scale ingots were cast, hot rolled and direct quenched into $12 \mathrm{~mm}$ thick plates as per an experimental plan. Tensile properties, impact toughness, hardness and hardenability were studied. In addition, coarse grained heat affected zone (CGHAZ) simulations were performed in a Gleeble simulator to evaluate the weldability of the investigated steels using cooling time from $800{ }^{\circ} \mathrm{C}$ to $500{ }^{\circ} \mathrm{C}\left(\mathrm{t}_{8 / 5}\right)$ of $5 \mathrm{~s}$ and $15 \mathrm{~s}$.
\end{abstract}

Keywords: CGHAZ, direct quenching, lower bainite, upper bainite

\section{INTRODUCTION}

In the last two decades there have been considerable advances in the theory and practice of accelerated cooling including direct quenching, following controlled rolling. Thermomechanical controlled processing (TMCP) has become the essence of processing low-carbon steel, particularly in combination with microalloying, in order to obtain the desired microstructures and properties [1]. In fact, TMCP represents the most effective manufacturing process to impart improved strength, ductility and low-temperature toughness in steels with reasonable hardenability, managed through controlled low carbon and alloy contents. The microstructure, which is the key to achieving a desired combination of mechanical properties in hot rolled steels, is greatly influenced by the quenching process following TMCP rolling. Hence, the microstructures and mechanical properties of particular low-carbon steel can be significantly improved by suitably designing the accelerated cooling/direct quenching process, following the hot deformation schedule [2]. Accelerated cooling may promote bainite formation with or without ferrite formation, depending on the alloy design and the cooling path. In this study, salient features of the successful development of a high strength, $0.035 \mathrm{C}$ low-carbon steel with yield strength on the order of $700 \mathrm{MPa}$ in combination with good ductility and toughness are presented with a special emphasis on structure-property correlations. TMCP combined with direct quenching process was employed to produce three different types of high-strength low-carbon bainitic steels with a constant niobium level of $0.06 \mathrm{wt} . \%$, but three different levels of chromium, (1.0, 2.5 and $4.0 \mathrm{wt} . \%)$. The aim of the study was to understand the effects of the combined additions of niobium and chromium on the microstructures and mechanical properties of $0.035 \mathrm{C}$ microalloyed bainitic steels. Besides, CGHAZ evaluation was planned to understand the occurrence of softening in welded structures and its effect on the microstructures and mechanical properties for different levels of chromium contents in the microalloyed steel.

\section{EXPERIMENTAL PROCEDURES}

The steel castings were procured from Outokumpu, Tornio, Finland as $70 \mathrm{~kg}$ vacuum-cast ingots. The chemical compositions of the three steels are listed in Table 1. $200 \mathrm{~mm} \times 80 \mathrm{~mm} \times 55 \mathrm{~mm}$ pieces of these castings were 
soaked at $1250^{\circ} \mathrm{C}$ for $2 \mathrm{~h}$ and thermomechanically rolled to $12 \mathrm{~mm}$ thick plates as per an experimental plan comprising several hot rolling passes in recrystallization controlled regime followed by controlled rolling passes in no-recrystallization regime $\left(T_{N R}\right)$. The temperature of the samples during rolling and direct quenching was monitored by placing thermocouples in the centre of the samples. The finish rolling temperature was controlled at around $880^{\circ} \mathrm{C}$ and the final thickness was $12 \mathrm{~mm}$ at this temperature prior to quenching. After hot rolling, direct quenching in a water tank was used to achieve a high cooling rate $\left(\sim 40-50^{\circ} \mathrm{C} / \mathrm{s}\right)$ in the centre of the samples.

Table 1 The chemical compositions of experimental steels (wt.\%).

\begin{tabular}{|c|c|c|c|c|c|c|c|}
\hline Steel & $\mathbf{C}$ & Nb & Cr & Si & Mn & S & Al \\
\hline $4 \mathrm{Cr}$ & 0.035 & 0.06 & 4.0 & 0.15 & 0.9 & 0.0034 & 0.037 \\
\hline $2.5 \mathrm{Cr}$ & 0.035 & 0.06 & 2.5 & 0.17 & 0.9 & 0.0030 & 0.045 \\
\hline $1 \mathrm{Cr}$ & 0.035 & 0.06 & 1.0 & 0.20 & 1.0 & 0.0030 & 0.045 \\
\hline
\end{tabular}

A Gleeble 3800 thermomechanical simulator was used to conduct simulation of the coarse-grained region of HAZ (CGHAZ) using samples of the size $10 \mathrm{~mm} \times 10 \mathrm{~mm} \times 55 \mathrm{~mm}$. Simulations were carried out in the Gleeble with the evacuated chamber and a free span of $10 \mathrm{~mm}$. The following thermal cycle was programmed: heating at $100{ }^{\circ} \mathrm{C} / \mathrm{s}$ to $1300^{\circ} \mathrm{C}$ and continued heating at $50^{\circ} \mathrm{C} / \mathrm{s}$ to $1350^{\circ} \mathrm{C}$, holding at $1350^{\circ} \mathrm{C}$ for $1 \mathrm{~s}$ to even out the temperature, followed by cooling corresponding to Rykalin-3D (thick plate) formulation based on conductive heat transfer, with a cooling time from 800 to $500{ }^{\circ} \mathrm{C}\left(\mathrm{t}_{8 / 5}\right)$ of 5 and $15 \mathrm{~s}$. After the simulation experiments, the Charpy $\mathrm{V}$-notch tests were performed at temperatures of $-40^{\circ} \mathrm{C}$ and $-60^{\circ} \mathrm{C}$. Besides, hardness profiles across the heat affected zones were determined with $0.5 \mathrm{~mm}$ spacing between the indentation as described below. The specimens used for microstructural evaluation, including optical microscopy and field emission scanning electron microscopy (FESEM), were mechanically polished and etched in a $2 \%$ nital solution. Electron backscatter diffraction (EBSD) analyses were carried out using an accelerating voltage of $15 \mathrm{kV}$, and a step size of $0.2 \mu \mathrm{m}$ and area of approximately $150 \mu \mathrm{m} \times 150 \mu \mathrm{m}$. Samples were polished with $0.04 \mu \mathrm{m}$ silica as the final step for EBSD analyses.

Longitudinal tensile flat specimens with thickness of $11.7 \mathrm{~mm}$, width of $20 \mathrm{~mm}$ and a parallel length of $120 \mathrm{~mm}$ were tested at room temperature using an MTS 810 mechanical testing machine fitted with a $100 \mathrm{kN}$ load cell and the measurements were based on the SFS-EN 10002-1 standard with 3 tests carried out for each composition. For toughness evaluation, the standard Charpy V-notch impact test specimens were sectioned in the longitudinal and transversal directions of the rolled samples for testing in the temperature range between $-120^{\circ} \mathrm{C}$ and $20^{\circ} \mathrm{C}$ using a $300 \mathrm{~J}$ Charpy testing machine. Hardness tests were done by using a DURAMIN A300 Vickers testing machine for all the rolled samples. A representative hardness value was obtained from the mean of 5 sets of seven suitably spaced hardness impressions through the thickness.

\section{RESULTS AND DISCUSSION}

\subsection{Microstructure}

Due to the application of accelerated cooling, all the steel plates displayed various low temperature transformation microstructures, viz., granular bainite (GB), upper bainite (UB), coalesced bainite, lower bainite (LB), as well as, quasi-polygonal ferrite (QF). Examples of different microstructural constituents observed by metallography are shown in Figure 1. Grain boundary maps with image quality data of EBSD acquisitions are presented in Figure 2. Grain misorientation distributions and grain sizes were determined using the EBSD data and are presented in Figure 3. Effective grain and lath sizes were determined as equivalent circle diameter $(E C D)$ values with low-angle $\left(2^{\circ}-15^{\circ}\right)$ and high angle $\left(>15^{\circ}\right)$ boundary misorientations. Also the effective high-angle grain sizes at 90 percentile in the cumulative size distribution ( $\mathrm{d}_{90} \%$ ) were determined. 
Based on the microstructural characterization and misorientation distribution measurements, clear differences between the three steels were apparent. With the highest $\mathrm{Cr}$ content $(4 \mathrm{Cr})$, microstructure consisted mainly lath-type structure such as UB and LB, which, therefore, had smallest grain sizes. As expected, decreasing the $\mathrm{Cr}$ content decreased the hardenability of steels and hence, resulted in more of granular bainite and ferrite in $2.5 \mathrm{Cr}$ and $1 \mathrm{Cr}$ steels. As the ferrite content increased, lath and effective grain sizes became bigger too, in comparison to that seen in steel $4 \mathrm{Cr}$.
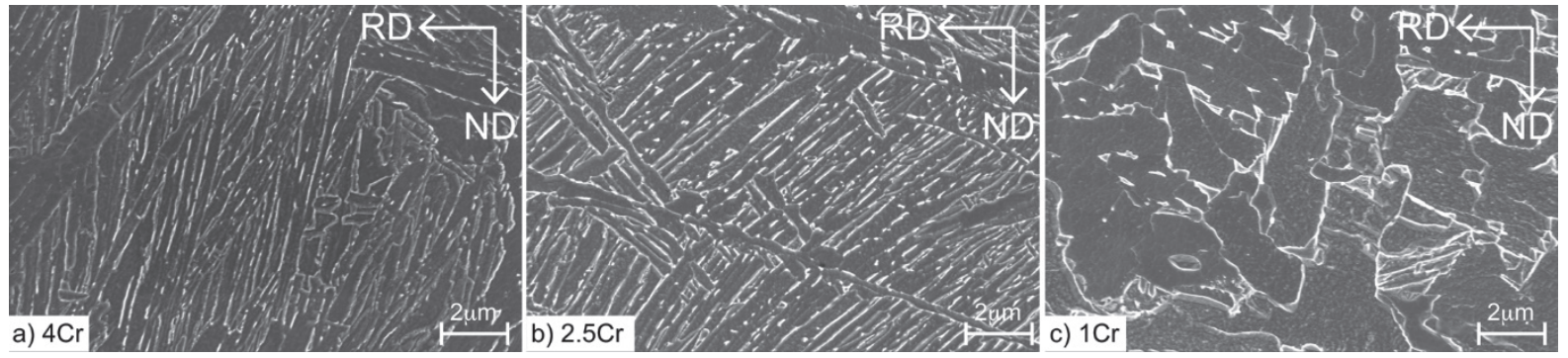

Figure 1 Typical microstructures of investigated steels. a) Upper bainite in $4 \mathrm{Cr}$ steel, b) lower bainite in $2.5 \mathrm{Cr}$ steel and c) quasi-polygonal ferrite and qranular bainite in $1 \mathrm{Cr}$ steel
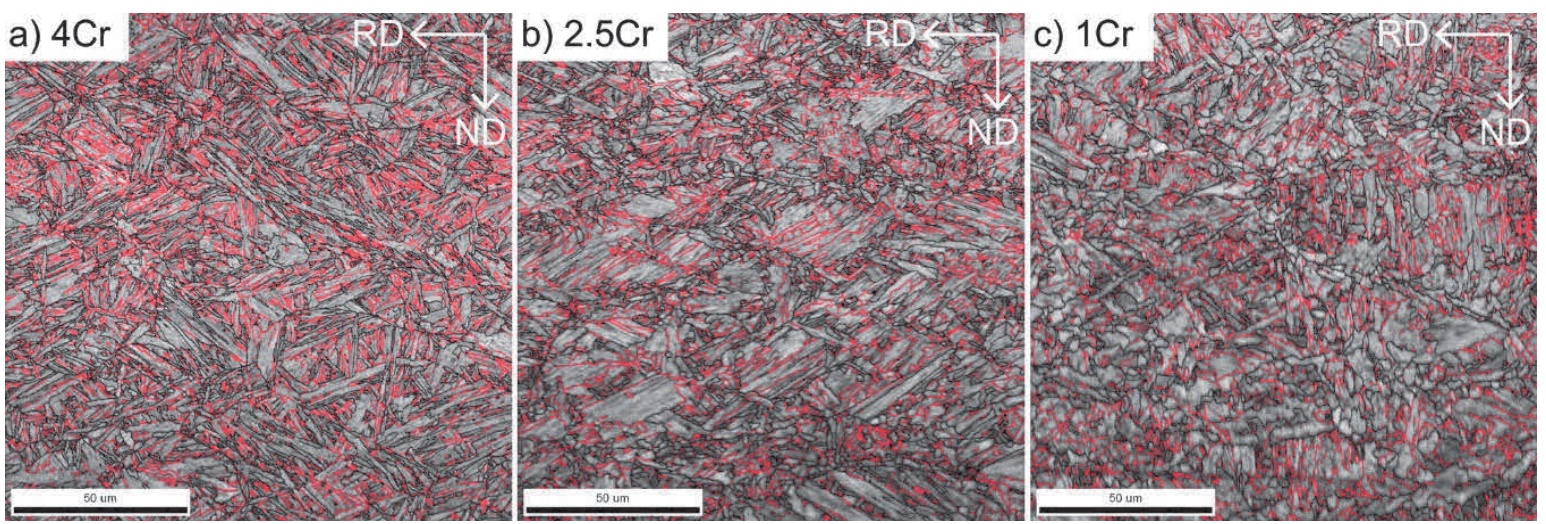

Figure 2 Grain boundary maps with image quality data of investigated steels. High-angle boundaries (>15 , black line) and low-angle boundaries $\left(2^{\circ}-15^{\circ}\right.$, red line $)$
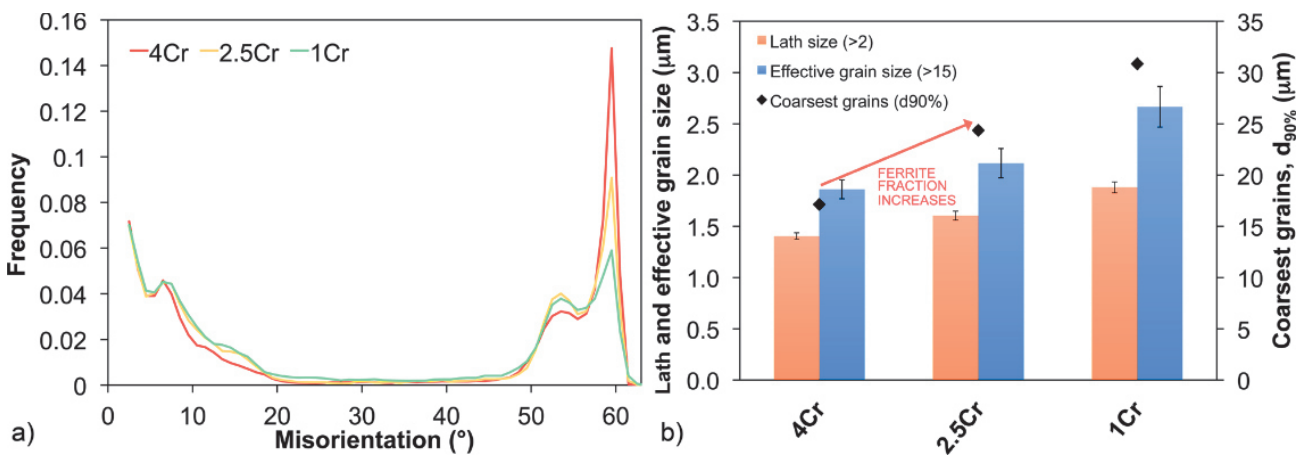

Figure 3 a) Grain boundary misorientation distributions and b) grain sizes of investigated steels measured by EBSD

\subsection{Mechanical properties}

A summary of the tensile test results for the three steels and the corresponding $28 \mathrm{~J}$ transition temperatures $\left(T_{28 \mathrm{~J}}\right)$ estimated from the impact tests are displayed in Table 2. Plots of through-thickness hardness profiles, representative engineering stress-strain curves and impact transition curves of the investigated steels are 
presented in Figure 4. In respect of the desired level of $700 \mathrm{MPa}$ yield strength, both the $4 \mathrm{Cr}$ and $2.5 \mathrm{Cr}$ steels were able to demonstrate similar tensile properties as in the industrial production [3], but the $1 \mathrm{Cr}$ steel showed lower yield strength ( $560 \mathrm{MPa}$ ) obviously as a consequence of the formation of quasi-polygonal ferrite, though the total elongation $(A)$ was relatively higher. The presence of quasi-polygonal ferrite and granular bainite with $\mathrm{M} / \mathrm{A}$ islands seem to have significant effect on the impact toughness of $1 \mathrm{Cr}$ steel, which is better than the higher $2.5 \mathrm{Cr}$ and $4 \mathrm{Cr}$ steels, both in respect of higher upper shelf energy as well as lower $\mathrm{T}_{28 \mathrm{~J}}$ temperature, as displayed in Table 2 and Figure 4c. A good toughness is known to be associated with a massive ferrite structure like quasi-polygonal ferrite [4]. On the other hand, thin films of martensite-austenite (M/A) constituents present in lath-like granular bainite might adversely affect the impact toughness [5]. Anyhow, the highest tensile properties and correspondingly, somewhat higher transition temperatures were achieved with the low-carbon ( $0.035 \mathrm{C}$ wt.\%) Nb-microalloyed, $4 \mathrm{Cr}$ TMCP rolled sample with the $\mathrm{FRT}$ controlled at $880{ }^{\circ} \mathrm{C}$, essentially due to the formation of fine bainitic structure and the absence of ferrite in the microstructure. In essence, steel with the yield strength of about $780 \mathrm{MPa}$ in direct quenched condition with the $\mathrm{T}_{28 \mathrm{~J}}$ transition temperature of around $-80^{\circ} \mathrm{C}$ can be considered as extremely good and meets the desired expectations.

Table 2 Mean tensile properties in longitudinal direction and corresponding $\mathrm{T}_{28 \mathrm{~J}}$ transition temperatures

\begin{tabular}{|c|c|c|c|c|c|c|c|}
\hline Steel & $\begin{array}{c}\text { YS } \\
(\mathrm{MPa})\end{array}$ & $\begin{array}{c}\text { UTS } \\
(\mathrm{MPa})\end{array}$ & $\begin{array}{c}\text { A } \\
(\%)\end{array}$ & HV10 & YS/UTS & $\begin{array}{c}\text { UTS*A } \\
(\mathbf{M P a} \%)\end{array}$ & $\begin{array}{c}\text { T28J }^{*} \\
\left({ }^{\circ} \mathbf{C}\right)\end{array}$ \\
\hline $4 \mathrm{Cr}$ & 780 & 982 & 12.5 & 312 & 0.79 & 12238 & -78 \\
\hline $2.5 \mathrm{Cr}$ & 699 & 909 & 14.1 & 293 & 0.77 & 12852 & -93 \\
\hline $1 \mathrm{Cr}$ & 560 & 756 & 17.2 & 251 & 0.74 & 13034 & -118 \\
\hline
\end{tabular}
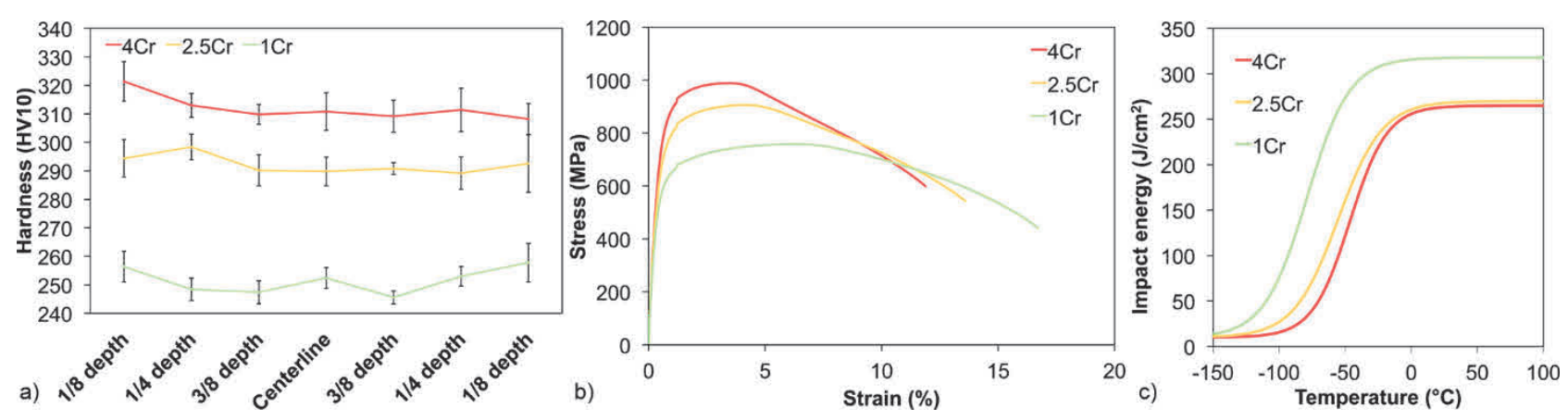

Figure 4 a) Through-thickness hardness profiles,

b) stress-strain curves and c) Charpy $V$ transition curves of investigated steels

Through-thickness hardness profiles made on the rolled samples are depicted in Figure $\mathbf{4 a}$ and the corresponding mean hardness values are summarized in Table 2. The adverse effect of the quasi-polygonal ferrite on hardness in $2.5 \mathrm{Cr}$ and $1 \mathrm{Cr}$ steels can be seen in Figure $4 \mathrm{a}$. The hardness dropped significantly in the case of $1 \mathrm{Cr}$ steel, where a fairly significant amount of QF did form in the microstructure (Figures 1c). Though $\mathrm{Cr}$ is a strong ferrite-stabilizing element, an increase in $\mathrm{Cr}$ content contrarily reduced the amount of ferrite (except for the increased solution hardening) due to the increased hardenability of the high chromium steels, $2.5 \mathrm{Cr}$ and $4 \mathrm{Cr}$, which therefore displayed enhanced hardness values, as shown in Table 2 [6]. A higher $\mathrm{Cr}$ addition resulted in less ferrite formation, thus facilitating an increased bainite fraction in the microstructure. It is reported that an increase in $\mathrm{Cr}$ content in the steel causes a separation of the bainite $\mathrm{C}$-curve from the ferrite C-curve (more clearly in the presence of Mo) and extends the bainite phase field [7]. The dilatometer studies did confirm a similar effect, further supporting the higher hardenability of high $\mathrm{Cr}$ steels [8]. The addition of $\mathrm{Cr}$ decreased the $\mathrm{B}_{\mathrm{s}}$ and $\mathrm{M}_{\mathrm{s}}$, which not only contributed to the higher fraction of bainite at a given cooling rate, but also promoted fine lath-type structure with enhanced strength and toughness. Moreover, due to higher 
hardenability of high-Cr steels, the hardness seems to be fairly uniform through the thickness (Figure 4a) besides, the better stability and uniformity of the microstructures. Therefore, more undercooled austenite can transform into lath-like bainite in the Cr-added steel, which may impart better properties, though the casting practice should be thoughtfully designed (both in respect of superheat and appropriate Cr-content) to prevent Cr- microsegregation bands in the microstructure.
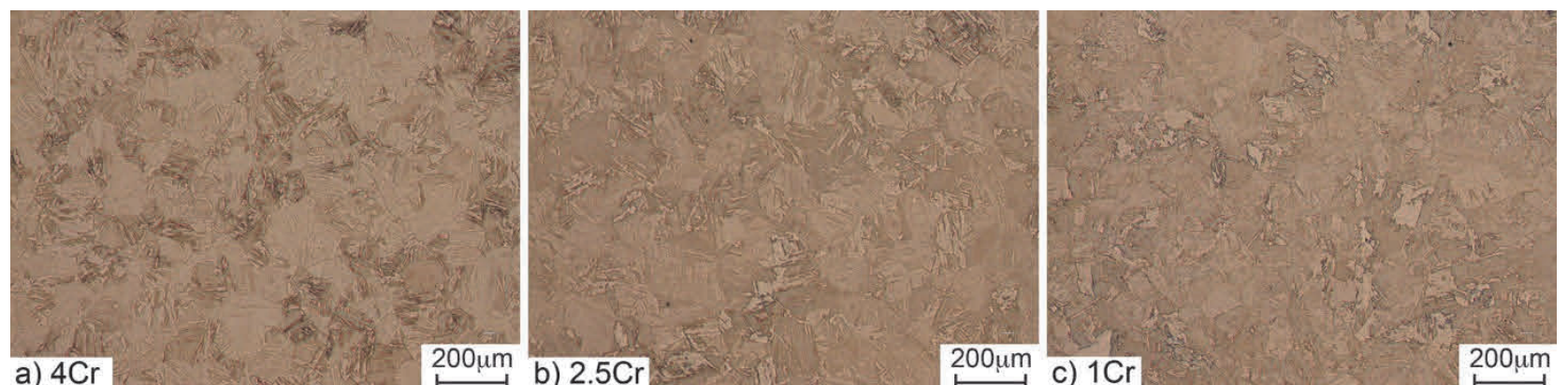

Figure 5 Representative microstructures of CGHAZ simulation samples using t $8 / 5=15 \mathrm{~s}$ cooling cycle

\subsection{HAZ simulation}

The microstructures of CGHAZ simulated samples with $t_{8 / 5}=15 \mathrm{~s}$ cooling cycle are presented in Figure 5 . Microstructures essentially consisted of mixtures of different bainite types, and also with small fractions of quasi-polygonal ferrite in $2.5 \mathrm{Cr}$ and $1 \mathrm{Cr}$ steels. Hardness measurements performed across the simulated CGHAZ samples are presented in Figures $6 \mathbf{a}$ and $\mathbf{b}$. The highest softening occurred in $1 \mathrm{Cr}$ and $2.5 \mathrm{Cr}$ steels at the CGHAZ regions with more softening occurring in samples with longer t8/5-time (15 s) (Figure 6a).
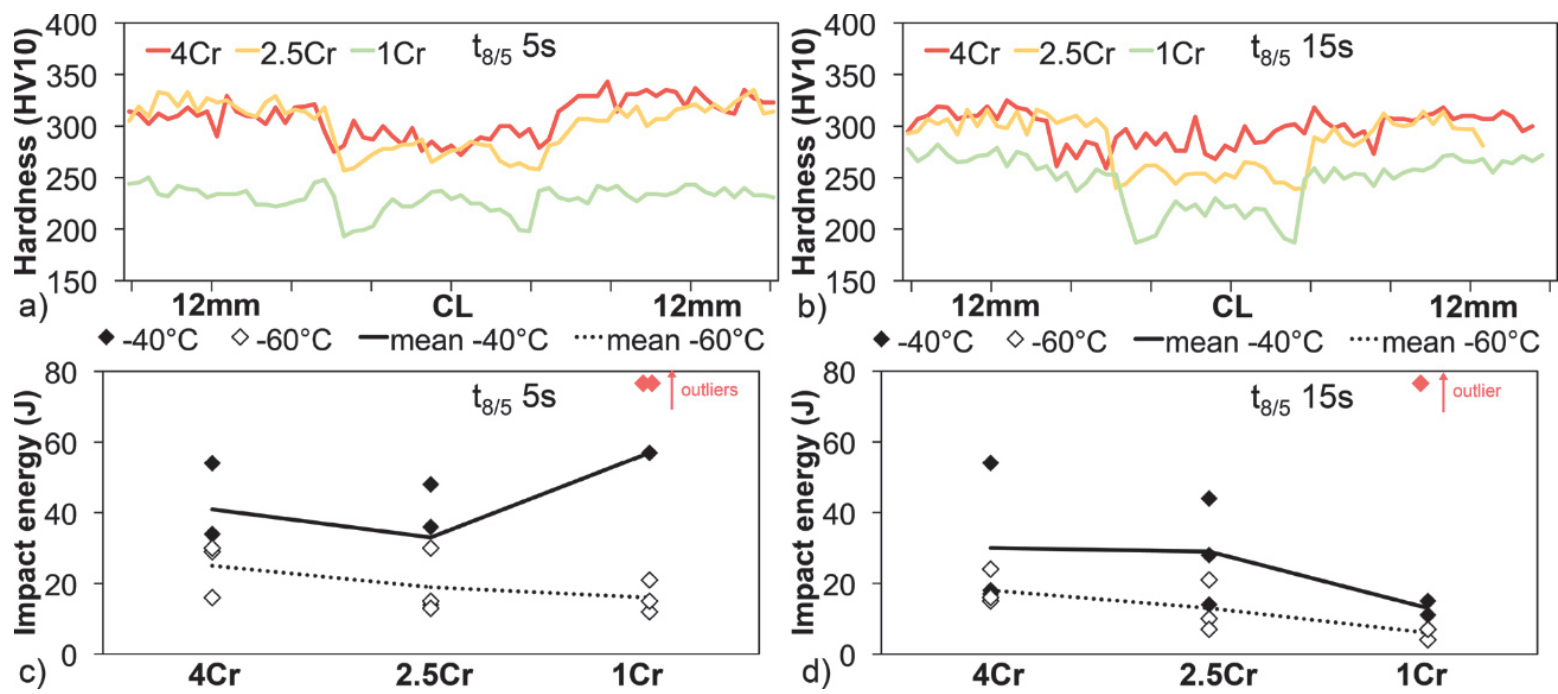

Figure 6 Hardness profiles across HAZ samples with t8/5 times of (a) $5 \mathrm{~s}$ and b) $15 \mathrm{~s}$; and corresponding Charpy $V$ impact toughness energies at $-40^{\circ} \mathrm{C}$ and $-60^{\circ} \mathrm{C}$ for t8/5 times of $\mathrm{c}$ ) $5 \mathrm{~s}$ and d) $15 \mathrm{~s}$. The CGHAZ regions in some Gleeble simulated samples of $1 \mathrm{Cr}$ steel were not clearly identifiable to correctly machining the notches and led to scatter in the results, marked as outliers (red coloured solid diamonds).

Higher $\mathrm{Cr}$ content $\left(4 \mathrm{Cr}\right.$ ) decreased the amount of softening in the HAZ region, especially with longer (15 s) $\mathrm{t}_{8 / 5}$ -time due to increased through-thickness hardenability (i.e. larger ideal critical diameter). The average hardness of $4 \mathrm{Cr}$ steel in direct quenched condition was $312 \mathrm{HV}$, whereas the CGHAZ simulated samples with $t_{8 / 5}=15 \mathrm{~s}$ showed a marginally lower hardness of $287 \mathrm{HV}$. This suggests that even with a longer t8/5 time of 15 $\mathrm{s}$, it should be possible for the HAZ area to achieve mechanical properties nearly similar to the base metal. 
The Charpy V impact test data for CGHAZ samples at $-40{ }^{\circ} \mathrm{C}$ and $-60{ }^{\circ} \mathrm{C}$ are plotted in Figures $6 \mathbf{c}$ and $\mathbf{d}$ for both the cooling cycles corresponding to $t_{8 / 5}=5$ and $15 \mathrm{~s}$. As can be seen in the figure, the CGHAZ simulated samples of $1 \mathrm{Cr}$ steel has displayed largest scatter in impact energy values $\left(11 \mathrm{~J}-212 \mathrm{~J}\right.$ ) at $-40{ }^{\circ} \mathrm{C}$, but the impact energies are lowest of all at $-60^{\circ} \mathrm{C}$. In all, $4 \mathrm{Cr}$ steel had the highest impact energies at both cooling cycle conditions ( $t_{8 / 5}=5$ and $15 \mathrm{~s}$ ). As expected, shorter $\mathrm{t}_{8 / 5}$ time $(5 \mathrm{~s})$ corresponding to the higher cooling rates (Figure 6c) gave better impact toughness properties compared to the longer duration $t_{8 / 5}=15 \mathrm{~s}$ samples (Figure 6d).

\section{SUMMARY AND CONCLUDING REMARKS}

The main aim of this report was to understand the effect of chromium on the microstructures and mechanical properties of $\mathrm{Nb}$-microalloyed $0.035 \mathrm{C}$ low carbon steel processed through TMCP rolling followed by direct quenching. The study also included weldability aspects of these $\mathrm{Cr}$-alloyed steels through Gleeble simulations. The programme envisaged high yield strength of the order of $700 \mathrm{MPa}$ in these steels with good ductility and improved low temperature toughness in direct quenched condition. Three laboratory-scale experimental steels with different $\mathrm{Cr}$ levels were processed through laboratory rolling simulations and evaluated in respect of mechanical properties and microstructures. A Gleeble 3800 thermomechanical simulator was employed to conduct the CGHAZ simulations with two different cooling cycles. The typical microstructures consisted of mainly mixtures of different type of bainite in all the three steels with the exception of $1 \mathrm{Cr}$ steel, which displayed significant fractions of quasi-polygonal ferrite, too. An increase in $\mathrm{Cr}$ content resulted in an increased hardness owing to an enhanced hardenability during direct quenching. A decrease in $\mathrm{Cr}$ content, however, promoted formation of quasi-polygonal ferrite, which in turn increased the impact toughness and elongation, but the required yield strength of $\geq 700 \mathrm{MPa}$ could not be achieved. CGHAZ simulation of $4 \mathrm{Cr}$ steel showed negligible softening and the impact toughness at $-40{ }^{\circ} \mathrm{C}$ was quite reasonable at about $45 \mathrm{~J} / \mathrm{cm}^{2}$. Thus, the $4 \mathrm{Cr}$ steel emerges as the potential candidate for $700 \mathrm{MPa}$ grade steel envisaged in this program owing to its high properties both in direct-quenched as well as welded conditions.

\section{REFERENCES}

[1] XIE, H., DU, L.X., HU, J. and MISRA, R. Devesh K. Microstructure and mechanical properties of a novel 1000 MPa grade TMCP low carbon microalloyed steel with combination of high strength and excellent toughness. Materials Science and Engineering. 2014. vol 612A, pp. 123-130.

[2] BANDYOPADHYAY, S., GHOSH, S., KUNDU, S. and CHATTERJEE, S. Evolution of Microstructure and Mechanical Properties of Thermomechanically Processed Ultrahigh-Strength Steel. Metallurgical and Materials Transactions. 2011. vol. 42A, no. 9, pp. 2742-2752.

[3] SSAB steel brochure. Available from: https://www.ssab.com/Products/Brands/Strenx/Products/Strenx-700-MC

[4] KRAUSS, G. and THOMPSON, S.W. Ferritic Microstructures in Continuously Cooled Low- and Ultralow-carbon Steels. ISIJ international. 1995. vol, 35. no. 8, pp. 937-945.

[5] BHADESHIA, H.K.D.H. Local Brittle Zones and the Role of Niobium. Materials Science Forum. 2014. vol. 783786, pp. 2129-2135.

[6] LEE, H.J. and LEE, H.W. Effect of Cr Content on Microstructure and Mechanical Properties of Low Carbon Steel Welds. International Journal of Electrochemical Science. 2015. vol. 10, pp. 8028-8040.

[7] ZHOU, L., LIU, Y., FANG, Y. and HUANG, Q.W. Effect of Cr on transformation of ferrite and bainite dual phase steels. Journal of Iron and Steel Research. 2009. vol. 21, no. 7, pp. 37-41.

[8] ALI, M., KAIJALAINEN, A., HANNULA, J., PORTER, D. and KÖMI, J. Influence of Chromium content and Prior Deformation on the Continuous Cooling Transformation Diagram of Low-Carbon Bainitic Steels. In $2^{\text {nd }}$ International Conference on Materials Science \& Engineering. In press. 